\title{
New Insights into Esca of Grapevine: The Development of Foliar Symptoms and Their Association with Xylem Discoloration
}

P. Lecomte, G. Darrieutort, J.-M. Liminana, and G. Comont, INRA, UMR1065 SAVE, Université de Bordeaux, ISVV, BP 81, 33883 Villenave d'Ornon cedex, France; A. Muruamendiaraz and F.-J. Legorburu, NEIKER-Tecnalia, Apartado 46, E-01080 Vitoria/Gasteiz, Basque Country, Spain; E. Choueiri, F. Jreijiri, and Roula El Amil, Lebanese Agricultural Research Institute, Department of Plant Protection, Tal Amara, Zahlé, Lebanon; and Marc Fermaud, INRA, UMR1065 SAVE, Université de Bordeaux, ISVV, BP 81, 33883 Villenave d'Ornon cedex, France

\begin{abstract}
Lecomte, P., Darrieutort, G., Liminana, J.-M., Comont, G., Muruamendiaraz, A., Legorburu, F.-J., Choueiri, E., Jreijiri, F., El Amil, R., and Fermaud, M. 2012. New insights into esca of grapevine: The development of foliar symptoms and their association with xylem discoloration. Plant Dis. 96:924-934.

A new study on the development of foliar symptoms of esca was carried out from 2004 to 2006 in five mature vineyards in Aquitaine, France. Symptoms were monitored for severity and changes over time. Initial foliar symptoms were characterized by the presence of drying zones or discolorations (reddening or yellowing), which are symptoms that have also been attributed to Black Dead Arm (BDA). Then, the less-severely affected leaves persisted throughout the summer and developed into typical "tiger-stripe" symptoms of esca. The most severely symptomatic leaves fell soon after symptoms appeared. Severely diseased vines showed typical apoplectic or acute forms of esca that did not differ from

the severe BDA forms. The appearance of leaf-symptomatic vines increased uniformly over time, reaching a maximum incidence by the end of July. A second survey in 41 European and Lebanese vineyards showed that longitudinal discolorations were visible under the bark of 95\% of the vines showing foliar esca symptoms. These wood symptoms, also previously attributed to BDA, appeared as xylem orange-brown stripes. Thus, foliar symptoms of esca showed transitory phases which overlapped with some BDA descriptions. Most of these symptoms, in the west-palearctic regions that were investigated, were commonly associated with the presence of one or several xylem discolorations.
\end{abstract}

Esca of grapevine, also known as "black measles", is such a complex disorder that some authors have described it as a complex of fungal diseases $(33,42)$. The etiology of this syndrome is still a matter for study, and many pathogenesis scenarios explaining the origin of foliar symptom expression are considered possible $(35,42)$. A large diversity of foliar and wood symptoms has been associated with esca and related declines (Table 1). No fungal parasite has been isolated from esca leaf lesions (47). Foliar symptoms appear in late spring or summer and are traditionally divided into two forms, depending on their severity and how rapidly they appear $(1,11,14,33)$. The acute or apoplectic forms are characterized by a rapid wilting of the entire plant or of one arm or several shoots, as well as leaf drop and shriveling and sometimes the drying of grape clusters $(1,11,14,33)$. The "chronic" or "mild" form is associated with foliar symptoms described internationally as showing a tiger-stripe pattern (33). In black-berried cultivars, this foliar symptom consists of characteristic multiple banding discolorations surrounding dry, brittle, light-brown or red-brown necrotic tissue on the leaf blade, which can appear as bordered by narrow red or yellow blotches. In white-berried cultivars, the red color is normally absent. Leaf color alterations may start as small, pale or bright-yellow spots between the primary veins, gradually enlarging and sometimes becoming necrotic at the center during the course

Corresponding author: P. Lecomte, E-mail: lecomte@bordeaux.inra.fr Accepted for publication 10 February 2012

http://dx.doi.org/10.1094/PDIS-09-11-0776-RE

This article is in the public domain and not copyrightable. It may be freely reprinted with customary crediting of the source. The American Phytopathological Society, 2012. of the growing season (33). Interestingly, only Viala (47) stressed that necrotic zones may also originate from drying zones that, at first, appear pale green to grayish green. Moreover, varying degrees of red colorations occur on the leaves of red-berried cultivars (47), which may include dark-red or wine-red symptoms, although these symptoms have also been attributed to the disease Black Dead Arm (BDA; 9,39). Because the wood of diseased vines is often severely decayed, the expression of foliar symptoms has been associated with the development of different fungi in the grapevine wood $(7,11,12,33,37)$. Cross-sections of the trunk reveal a variety of lesions or decay types $(20,29,32)$, which all impact the vascular system. It is generally agreed that these lesions will continue to expand as the plant ages, until the vine declines $(25,33,42)$. In older vines, the wood usually shows a white to yellow soft rot, from which lignin-degrading basidiomycetes like Fomitiporia spp. (in Europe, usually Fomitiporia mediterranea) can be isolated (12). Esca lesions are also associated with different fungi, including Phaeo's species $(33,42)$, but many other species considered to be either saprobes or pathogenic could be also involved in the development of the esca syndrome (35).

BDA is another disease described as having slightly different foliar symptoms than those associated with esca (22). This wood disease was first described in 1974 by Lehoczky (28), who reported only the wood canker and no foliar symptoms $(18,28)$. Moreover, another wood symptom was also later described as characteristic of BDA: the occurrence of an orange, then brown, xylem discoloration appearing always associated with the foliar symptoms (22). Located in the outer xylem, this peculiar wood discoloration symptom appears as a superficial, longitudinal stripe just beneath the bark. The first link between cankers associated with Botryosphaeriaceae species, and a reddening on the leaf blade of black cultivars was documented in 1978 and 1987 in Italy $(9,39)$. Similarly, in France, foliar symptoms described as typical were 
reported from black-berried cultivars, beginning as drying zones or wine-red areas on the margins and on interveinal areas of the leaf blade (22).

Botryosphaeriaceae species have been isolated from these BDA wood lesions $(9,22,39)$. More generally, members of the Botryosphaeriaceae family are presently considered to be the causal agents of diverse trunk cankers of grapevine (2,6,17,31,36,43-45). In Australia, South Africa, and the United States, these fungi have been recovered from wedge-shaped wood cankers, which are typical of the disease Botryosphaeria canker of grapevine $(40,41,44,46)$. Parts of these sectorial cankers were originally thought to be due solely to Eutypa lata, the causal agent of Eutypa dieback, whereas the importance of Botryosphaeriaceae species as primary pathogens of grape was largely ignored (17). We now know that these species can also be isolated from all types of lesions encountered in vines that are simultaneously affected by either Eutypa dieback or esca $(3,34)$. Canopy symptoms most often reported from vines with Botryosphaeriaceae-associated cankers are bud mortality, mild chlorosis, slow decline, or reduced vegetative growth $(4,30,36,43,44,46)$. Interestingly, these studies did not associate the Botryosphaeriaceae cankers with any foliar reddening during summer on black cultivars, such as those attributed to BDA $(9,22,39)$. Thus, although the status of members of the Botryosphaeriaceae family as grapevine pathogens has been well documented, the relationship between the presence of these fungi within the grapevine wood and the occurrence of foliar symptoms of BDA, similar to those of esca, is still not clear. This may be due to the fact that foliar symptoms of BDA have not been investigated thoroughly and that the mixed-fungal infections we commonly encounter in the field confound our ability as researchers to associate specific symptoms with individual diseases.

Some authors, as well as preliminary observations in French vineyards, indicated that esca and BDA foliar symptoms may be related, because they are frequently observed on the same vine $(13,23,27,42,43)$. For the same reason, field observers from the French National Wood Disease Survey considered it to be a single foliar symptom category, "BDA-esca" (13). In this context, we have revisited BDA-esca symptoms, hypothesizing that symptom variability may result from a temporal change in symptom development. The two main objectives of our study were to show (i) the occurrence of a temporal development of foliar symptoms of esca and (ii) the consistent association of a xylem stripe under the bark of vines with foliar symptoms of esca. The first objective included the examination of a possible connection between foliar symptoms of esca and those attributed to BDA. In order to achieve these objectives, it was necessary to carry out surveys relying on precise observations (i.e., within individual vines and within a vineyard) to acquire basic information on the development of such a complex symptomatology.

\section{Materials and Methods}

Description and development of foliar symptoms in Aquitaine vineyards. In the Aquitaine region, five vineyards were studied from 2004 to 2006 (Table 2), to observe and assess the evolution of foliar symptoms over the summer. These vineyards were selected due to their high potential for esca expression, rare Eutypa dieback incidence, and low mortality due to other causes. Between 500 and 1,072 vines per vineyard were randomly sampled. All vineyards were mapped and the status of each vine was recorded using an adapted scale (Table 3) previously devised for esca and Eutypa dieback symptoms (10). This scale corresponded to the presence or absence of foliar symptoms (leaf-symptomatic vines or leaf-asymptomatic, respectively), as well as trunk-affected vines (dead arm present or cut, restored vine, dead vine, replanted vine, and so on). Foliar symptom severity was assessed based on involvement of one or both arms of the vine (Table 2) and levels of leaf damage from the less-severe (discolorations and spotting) to the most-severe (large drying zones, wilting, and defoliation) symptoms, including the apoplectic form. Each vineyard was then characterized each year according to the overall percentage of trunk-affected vines, as well as the general incidence of vines with foliar symptoms whatever their severity level. Percentages were ranked following pairwise comparisons using a parametric $z$ test based on the binomial distribution $(P$ value threshold $=1.96$, with $P=0.05$ considered to be significant; Statbox Pro, version 5; Grimmersoft, Issy-les-Moulineaux, France).

In 2004, at least six observations were recorded from mid-June (around mid-flowering) to the end of August or September (berry maturation stage). In 2005, vines were assessed on all sites from early June to the beginning of September at least once per week. In 2006, vineyards in Cénac and Latresne were investigated more thoroughly by surveying the sites twice per week in order to record foliar symptoms almost as soon as they emerged. Foliar symptoms were recorded for each symptomatic vine as one of three categories: (i) $\mathrm{B}=\mathrm{BDA}-\mathrm{like}$ symptoms, leaves with typical interveinal reddening or the presence of drying zones, the latter of which may

Table 1. Diversity of symptoms as reported in a selected literature review related to esca or to Black Dead Arm descriptions ${ }^{\mathrm{x}}$

\begin{tabular}{|c|c|c|c|c|c|c|}
\hline \multirow[b]{2}{*}{ Disorder, reference } & \multicolumn{2}{|c|}{ Wood symptom } & \multicolumn{4}{|c|}{ Foliar symptoms } \\
\hline & Internal & Stripe & Drying, dropping & Reddening & Yellowing & Chlorosis \\
\hline \multicolumn{7}{|l|}{ Esca } \\
\hline Viala 1926 (47) & $\mathrm{X}$ & $\ldots$ & $\begin{array}{l}\mathrm{X}, \text { green, } \\
\text { pale gray, brown }\end{array}$ & Red \pm bright & Variable & $\mathrm{X}$ \\
\hline Arnaud and Arnaud 1931 (1) & $\mathrm{X}$ & $\mathrm{X}$, light brown & $\mathrm{X}$ & $\ldots$ & $\mathrm{X}$, veining & $\mathrm{X}$ \\
\hline Ciferri $1955(8)$ & $\mathrm{X}$ & $\mathrm{X}, 1-2 \mathrm{~cm}$, brown & $\mathrm{X}$, gradual & Variable & $\mathrm{X}$ & $\ldots$ \\
\hline Chiarappa 1959 (7) & $\mathrm{X}$ & $\ldots$ & $\mathrm{X}$ & Dark red & $\mathrm{X}$, clearing & $\mathrm{X}$ \\
\hline Geoffrion 1971 (15) & $\mathrm{X}$ & $\ldots$ & $\mathrm{X}$ & $\mathrm{X}$ & $\mathrm{X}$ & $\mathrm{X}$ \\
\hline Branas $1974(5)$ & & $\ldots$ & & $\ldots$ & & $\ldots$ \\
\hline Galet 1995 (14) & $\mathrm{X}$ & $\mathrm{X}$, brown & $\mathrm{X}$ & $\ldots$ & $\mathrm{X}$ & $\ldots$ \\
\hline Mugnaï et al. 1999 (33) & $\mathrm{X}$ & $\ldots$ & $\mathrm{X}$ & Tiger-striped pattern & $\mathrm{X}$ & $\ldots$ \\
\hline Dubos $2002(11)$ & $\mathrm{X}$ & $\ldots$ & $\mathrm{X}$ & $\mathrm{X}$ & $\mathrm{X}$ & $\mathrm{X}$ \\
\hline Larignon 2004 (20) & $\mathrm{X}$ & $\ldots$ & $\mathrm{X}$ & Tiger-striped pattern & $\mathrm{X}$ & $\ldots$ \\
\hline Surico et al. 2006 (42) & $\mathrm{X}$ & $\mathrm{X}$ & $\mathrm{X}$ & Tiger-striped pattern, variable & $\mathrm{X}$ & $\ldots$ \\
\hline Black dead arm & $\ldots$ & $\ldots$ & $\ldots$ & $\ldots$ & $\ldots$ & $\ldots$ \\
\hline Lehoczky 1974 (28) & $\ldots$ & $\mathrm{X}$, black canker & & $\ldots$ & $\ldots$ & $\ldots$ \\
\hline Cristinzio 1978 (9) & $\ldots$ & $\mathrm{X}$, dark & $\mathrm{X}$ & $\mathrm{X}$ & $\ldots$ & $\mathrm{X}$ \\
\hline Rovesti and Montermini 1987 (39) & $\mathrm{X}^{\mathrm{y}}$ & $\mathrm{X}$ & $\mathrm{X}^{\mathrm{z}}$ & Wine red & $\mathrm{X}$ & $\ldots$ \\
\hline Larignon et al. 2001 (22) & $\ldots$ & $\mathrm{X}$ & $\mathrm{X}$ & Wine red, dark & None & $\ldots$ \\
\hline Larignon and Dubos 2001 (21) & $\ldots$ & $\mathrm{X}$ & $\mathrm{X}$ & Wine red & $\mathrm{X}$, variable & $\mathrm{X}$ \\
\hline Auger et al. 2004 (2) & $\ldots$ & $\mathrm{X}$, canker & $\mathrm{X}$ & $\mathrm{X}$ & $\ldots$ & $\ldots$ \\
\hline
\end{tabular}

${ }^{\mathrm{x}} \mathrm{X}$ indicates symptom described in this reference and ... indicates that the corresponding symptom has not been described in the reference.

y Diffuse or limited cankers in the xylem.

${ }^{\mathrm{z}}$ Leaves can remain attached. 
be surrounded by a reddening area specifically on red or black cultivars (Fig. 1A-I) or, on white cultivars, drying zones that may be accompanied by interveinal chlorosis, as described by Larignon et al. (21); (ii) $\mathrm{E}=$ leaves with esca-like symptoms, namely presence or absence of necrotic zones, various discolorations, and a typical "tiger-stripe" pattern (Fig. 1M-P); and (iii) $\mathrm{BE}=$ both symptom patterns observed on the same vine simultaneously (Fig. 1J-L).

Presence of vascular discoloration in European and Lebanese vineyards. From 2004 to 2007, 41 vineyard plots were monitored in different European and Lebanese regions, in addition to four of the five Aquitaine vineyards described above. The relationship between the presence of discoloration under the bark and the foliar symptoms (B and $\mathrm{BE}$ versus $\mathrm{E}$ ) in symptomatic versus asymptomatic vines (Tables 2 and 4) was investigated. The sites were distributed in 34 different locations: 24 sites in France, 8 in central Lebanon (Bekaa valley), 1 in northern Spain (Rioja Alavesa, Basque Country), and 1 in southwestern Germany (Tables 2 and 4). Agricultural practices were representative of each region. Vines were randomly selected among symptomatic plants that showed typical and marked foliar symptoms affecting a cane or several leaves. Foliar symptoms were assessed as described above.

Discolorations that appeared as longitudinal stripes along the length of canes or trunks were revealed by detaching some pieces of the bark with a knife as soon as the foliar symptoms were seen in Aquitaine. For leaf-asymptomatic vines, we completely peeled off the bark. The 34 vineyard sites surveyed provided a total of 688 grapevines: 581 leaf-symptomatic and 107 nonsymptomatic. The 581 symptomatic vines were further divided into two subgroups: 104 vines with BDA-like symptoms (B or BE) and 477 vines with esca-like symptoms (E). These distributions of vine counts were compared using both two-factor contingency tables $\left(\chi^{2}\right.$ test) and Fisher's exact test at $P=0.05$.

During the survey, the location of the stripes within the vine architecture and the sap routes was observed for 452 leaf-sympto- matic vines. In particular, we looked for the presence of stripes located either close to and along old longitudinal externally visible, cankers or in a line on either side of pruning wounds (sap route). In September 2007, a set of 29 vines showing typical esca symptoms was examined for the presence of stripes in the Latresne vineyard (Table 2). The location of each stripe was performed by slightly lifting the bark with a knife at two or three small spots $\left(1 \mathrm{~cm}^{2}\right)$. Stripes were then labeled in situ with a drawing pin. In September 2008, the fate of the xylem stripes was checked for the possible development of a trunk canker.

\section{Results}

Description and development of foliar symptoms in the Aquitaine region. The incidence of trunk and foliar symptoms varied greatly on the vines (2004 to 2006; Table 5). As expected, the percentage of trunk-affected vines increased year after year and the differences between sites were significant. Vineyards located at Ludon-Médon, Cénac, and Labarrère showed more than $30 \%$ incidence of trunk-affected vines, whereas the percentages were much lower in Latresne and Ramouzens. In 2006 (and 2005 as a trend), the highest percentage of vines expressing foliar symptoms $(55.6 \%)$ and one of the lowest incidences of declining vines $(9.6 \%)$ occurred in the Lyra-trained vineyard of Latresne.

Marked gradations of foliar symptom ratings were noticeable with regard to symptom severity and qualitative development at either the leaf level or the vine level. Symptom expression was gradual and characterized by an increasing number of affected leaves on one or more shoots as well as on one or more arms, affecting the entire plant canopy at the final stage. Three main categories (namely I, II [including IIA and IIB] and III, explained below) could be defined according to the level of damage (extent of drying areas) and symptom evolution. In all sites, the first foliar symptoms to appear (Figs. 1A-I and 2A, B, E, F, I, and M) corresponded mostly to BDA foliar symptoms, as described previously (22). In black cultivars, they were characterized as interveinal

Table 2. Main characteristics of the five Aquitaine vineyards (southwest of France) surveyed from 2004 to 2006 to examine the temporal evolution of escalike and Black Dead Arm-like foliar symptoms and the occurrence of longitudinal discolored stripes

\begin{tabular}{|c|c|c|c|c|c|c|c|}
\hline Vineyard location $^{y}$ & Cultivar & Rootstock & Training system & $\begin{array}{c}\text { Date of } \\
\text { planting }\end{array}$ & $\begin{array}{c}\text { Years of } \\
\text { observation }\end{array}$ & $\begin{array}{c}\text { Number of } \\
\text { vines surveyed }\end{array}$ & $\begin{array}{c}\text { Number of } \\
\text { vines } \\
\text { peeled }^{\mathrm{z}}\end{array}$ \\
\hline \multirow[t]{2}{*}{ Ludon-Médoc, Gironde, Médoc } & \multirow[t]{2}{*}{ 'Cabernet Sauvignon' } & \multirow[t]{2}{*}{$5 \mathrm{BB}$} & \multirow[t]{2}{*}{ Guyot, low form } & \multirow[t]{2}{*}{1981} & 2004 & 1,000 & 25 \\
\hline & & & & & 2005 & 1,000 & $72+21$ \\
\hline \multirow[t]{3}{*}{ Cénac, Gironde, Entre-Deux-Mers } & \multirow[t]{3}{*}{ 'Cabernet Franc' } & \multirow[t]{3}{*}{$3309 \mathrm{C}$} & \multirow[t]{3}{*}{ Guyot, high form } & \multirow[t]{3}{*}{1988} & 2004 & 500 & 6 \\
\hline & & & & & 2005 & 500 & 4 \\
\hline & & & & & 2006 & 550 & 2 \\
\hline \multirow[t]{3}{*}{ Latresne, Gironde, Entre-Deux-Mers } & \multirow[t]{3}{*}{ 'Cabernet Franc' } & \multirow[t]{3}{*}{ Fercal } & \multirow[t]{3}{*}{ Lyra, high form } & \multirow[t]{3}{*}{1987} & 2004 & 1,072 & - \\
\hline & & & & & 2005 & 500 & - \\
\hline & & & & & 2006 & 500 & - \\
\hline Ramouzens, Gers, Armagnac & 'Colombard' & Gravesac & Guyot, high form & 1990 & 2006 & 500 & 73 \\
\hline Labarrère, Gers, Armagnac & 'Colombard' & $\mathrm{SO} 4$ & Guyot, high form & 1989 & 2006 & 500 & 83 \\
\hline
\end{tabular}

${ }^{\mathrm{y}}$ Municipality, department, appellation of the wine.

${ }^{\mathrm{z}}$ Number in bold italics indicates number of leaf-asymptomatic vines examined as controls.

Table 3. Field rating used to assess the sanitary status (trunk symptoms) and the severity of foliar symptoms on the vines

\begin{tabular}{|c|c|}
\hline \multicolumn{2}{|r|}{ Observation of the whole vine } \\
\hline Trunk symptoms ${ }^{y}$ & Foliar symptom incidence $^{z}$ \\
\hline Arm entirely or partially dead (DA) & Leaf-asymptomatic vine $=0$ \\
\hline Missing $\operatorname{arm}(\mathrm{U})$ & Mild form on one arm, restricted defoliation, limited drying or discoloration $=1$ \\
\hline $\mathrm{U}=$ dead arm cut by pruning & Mild form on two arms, restricted defoliation, limited drying or discoloration $=2$ \\
\hline Low growth, suffering vine (S) & Severe foliar symptoms on one arm, drying, defoliation $=3$ \\
\hline Dead vine $(\mathrm{M})$ & Mild foliar symptom on one arm and a severe one on the others $=1+3$ \\
\hline Absent $(A)$ & Severe foliar symptoms on two arms and several canes, drying, defoliation $=4$ \\
\hline Replanted vine (CP) & Very severe foliar symptoms on two arms, acute defoliation $=5$ \\
\hline Young vine $(\mathrm{J})$ & Severe wilting on one arm, apoplectic form = Apo1 \\
\hline Retrained vine $(\mathrm{R})$ & Severe wilting on two or more arms or on the entire vine (dieback) $=$ Apo 2 \\
\hline
\end{tabular}



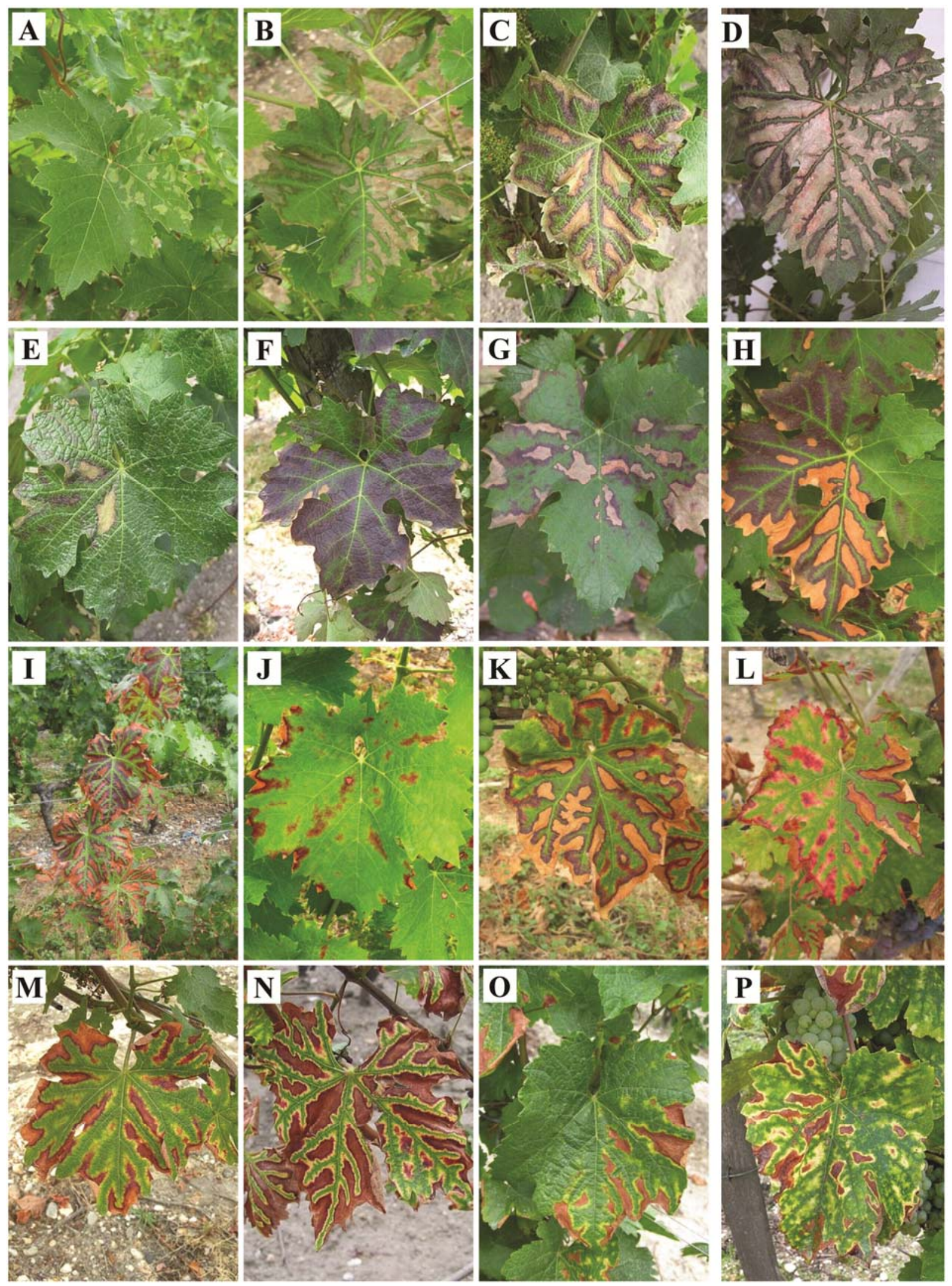

Fig. 1. Typical foliar symptoms taken into account beforehand for the disease-like classification, which varied depending on cultivar (black or white), symptom age, and severity (with the exception of wilted leaves). A-I, Early symptoms that were classified as Black Dead Arm (BDA)-like symptoms, with no presence of yellow tissue (class B). J-L, Leaves that simultaneously presented BDA-like and esca-like symptoms (class BE). M-P, Typical esca symptoms (class E), including the tiger-striped pattern with a yellow band between the green and red or necrotic tissue ( $\mathrm{M}$ and N). A-N, Black cultivars and $\mathbf{O}$ and $\mathbf{P}$, white cultivars. A-E and $\mathbf{G}$, Symptoms less than 3 to 4 days old. $\mathbf{F}$ and H-P, Symptoms several days or a few weeks old. Severe symptoms generally showed large drying zones on the lamina (D; category I); afterward, this kind of leaf generally falls rapidly. Intermediate symptoms (category IIA) concern leaves showing large or small interveinal drying zones with few changes in coloration during summer (N). Mild symptoms (category IIB) include limited drying zones, reddening (black cultivar), discolorations, and color changes depending on symptom age (A-C, E-M, and OP). Late or secondary symptoms (category III) mostly consist of limited discolored spots that appeared on the lamina after the drying zones (P compared with 0 ). 
drying or a wine-red pigmentation of the lamina whereas, in white cultivars, the pigmentation was yellow and appeared less frequently.

The primary symptoms were separated into the two main categories (I and II) according to their severity. Category I corresponded to very severely affected leaves. These leaves generally exhibited very large drying zones and little or no pigmentation (Fig. 1D). Most of them fell rapidly after several hours or days (defoliation). In the most severe cases, leaves were wilted ("folletage"), indicating an apoplectic form (Fig. 3J). Nevertheless, some leaves dried and remained attached to the canes (Fig. 2P). Category II comprised foliar symptoms of intermediate or lower severity that remained attached to the canes. Two subgroups were then established, depending on the development of the affected zones and the occurrence of newly damaged zones. In IIA, leaves showed large or small interveinal drying zones with few changes in coloration during summer (Figs. $1 \mathrm{~N}$ and $2 \mathrm{G}$ and $\mathrm{H}$ compared with F). In IIB, mildly damaged leaves showed wine-red (black cultivar) or yellowish discolored zones (white cultivar) with generally limited or no drying zones (Figs. 1 A, E-G, and O and 2A, E, I, and M). Different color development or new discolorations could then appear in the lamina during the summer. On black cultivars, most leaves exhibiting such wine-red pigmentation at an early stage generally showed typical esca tiger-striped patterns a few days or weeks later (Fig. 2). For white cultivars, the development mostly consisted of the emergence of a yellow discoloration around the drying zones and also elsewhere on the lamina (Fig. 10 and P).

Category III consisted of various mild secondary symptoms (mainly discolorations) that appeared either on symptomatic leaves, as described earlier, or in their vicinity on the same or a neighboring cane (Figs. $1 \mathrm{P}$ and $2 \mathrm{~K}$ and $\mathrm{L}$ compared with $\mathrm{J}$ and $\mathrm{O}$ compared with $\mathrm{N}$ ). These secondary symptoms developed mostly at the end of the season. Such symptoms could vary according to the cultivar and vineyard. They notably occurred in Lebanon on vines with several arms, where at least one arm was frequently affected by severe symptoms of wilting. Some of these symptoms were very similar to the color changes associated with natural leaf senescence that usually occur in autumn. Finally, all the previously described categories (I, IIA, IIB, and III) could be detected on the same cane. The severity of foliar symptoms could also significantly increase during the course of the season (Fig. $2 \mathrm{~L}$ compared with I$\mathrm{K}$ and $\mathrm{P}$ compared with $\mathrm{M}-\mathrm{O}$ ), and severely affected vines (acute forms) could also become completely apoplectic.

The results for the vineyard as a whole showed a general progressive pattern, with a regular and sigmoidal increase in the number of vines exhibiting typical foliar symptoms throughout the summer (Fig. 4). In every situation (vineyard-year combination), vines exhibited on the same symptomatic part of the canopy the three profiles of foliar symptoms consecutively. The first typical foliar symptoms to appear corresponded mostly to BDA-like ones and were recorded as early as the beginning of June. In contrast, typical esca-like symptoms were rare at first. Subsequently, the number of vines showing BDA-like symptoms increased and generally reached a maximum by the end of July. During the same period and in parallel, many vines showed different foliar discolorations or deteriorations that corresponded to both BDA-like and esca foliar symptoms. The progression of such mixed symptoms reached a maximum between the end of July and the beginning of August. Finally, in late August to September, a great number of symptomatic vines showed a characteristic esca tiger-striped pattern on the leaves that did not completely dry or fall during the summer.

Apoplectic forms on one or several arms were seen on all sites but more frequently on two sites (Cénac and Ludon-Médoc) in 2005. The Cénac site best exemplified a number of apoplectic vines that gradually and slightly increased up to the end of the

Table 4. Main characteristics of vineyards surveyed for the presence of sub-cortical and longitudinal discolored xylem stripes in European and Lebanese vineyards (2004 to 2007)

\begin{tabular}{|c|c|c|c|}
\hline Vineyard location $^{x}$ & Climate $^{\mathrm{y}}$ & Cultivar (number of vines examined) ${ }^{\mathrm{z}}$ & Year \\
\hline Castelnau d'Auzan, Aquitaine (F) & A & Ugni Blanc (1) & 2004 \\
\hline Bonnetan, Aquitaine $(\mathrm{F})$ & A & Cabernet Franc (3) & 2004 \\
\hline St. Médard d'Eyrans, Aquitaine (F) & A & Cabernet Sauvignon (2) & 2004 \\
\hline St. Julien-Beychevelle, Aquitaine (F) & A & Cabernet Sauvignon (1) & 2005 \\
\hline Cahors, Aquitaine $(\mathrm{F})$ & A & Merlot (1), Malbec (1) & 2005 \\
\hline Gaillac, Midi-Pyrénées (F) & A & Fer Servadou (3) & 2005 \\
\hline Eauze, Aquitaine (F) & A & Colombard (4), Baco $(2+1)$ & 2005 \\
\hline Edde-Aana, West Bekaa (L) & M & Cinsault (4) & 2005 \\
\hline Skaff-Ammiq, West Bekaa (L) & M & Cinsault (3), Tfaifihi (1) & 2005 \\
\hline Ksara, Estephan, West Bekaa (L) & M & Cabernet Sauvignon (2) & 2005 \\
\hline Kanafar, West Bekaa (L) & M & Chardonnay (1), Merlot (1) & 2005 \\
\hline Kefraya, West Bekaa (L) & M & Cinsault (7) & 2005 \\
\hline Kouroum-Kefraya West Bekaa (L) & M & Syrah (6) & 2005 \\
\hline Mansoura, Central Bekaa (L) & M & Cinsault (1) & 2005 \\
\hline Tanail, Central Bekaa (L) & M & Cinsault (8), Ugni Blanc (4) & 2005 \\
\hline Gruissan, Languedoc-Roussillon (F) & M & Mourvèdre (23) & 2006 \\
\hline Villeneuve les Maguelonne, Languedoc-Roussillon (F) & M & Danuta (15) & 2006 \\
\hline Castries, Languedoc-Roussillon (F) & M & Cabernet Sauvignon (26) & 2006 \\
\hline Fronsac, Aquitaine $(\mathrm{F})$ & A & Cabernet Franc $(20+21)$ & 2006 \\
\hline Villenave d'Ornon, Aquitaine (F) & A & $\begin{array}{l}\text { Cabernet Franc (1), Cabernet Sauvignon (8), Chasselas (2), } \\
\text { Chenin (3), Clairette (1), Gamay (1), Gewurztraminer (3), } \\
\text { Pinot gris (1), Pinot noir (1), Riesling (1), Syrah (2) }\end{array}$ & 2006 \\
\hline Elvillar, Rioja Alavesa (S) & M & Tempranillo $(26+15)$ & 2006 \\
\hline Avize, Champagne $(\mathrm{F})$ & $\mathrm{C}$ & Chardonnay (7) & 2007 \\
\hline Avize, Champagne (F) & $\mathrm{C}$ & Pinot noir (7) & 2007 \\
\hline Colmar, Alsace (F) & $\mathrm{C}$ & Gewurztraminer (7) & 2007 \\
\hline Ammerschwihr, Alsace (F) & $\mathrm{C}$ & Riesling (6) & 2007 \\
\hline Beaune, Burgundy $(\mathrm{F})$ & $\mathrm{C}$ & Pinot noir (21) & 2007 \\
\hline Jonzac, Poitou-Charentes (F) & A & Ugni Blanc (24) & 2007 \\
\hline Ludon-Médoc, Aquitaine (F) & A & Cabernet Franc $(26+26)$, Cabernet Sauvignon $(25+23)$ & 2007 \\
\hline Freiburg-im-Breisgau, Baden-Württemberg $(G)$ & $\mathrm{C}$ & Muller-Turgau (1), unknown (2) & 2007 \\
\hline
\end{tabular}

${ }^{x}$ Municipality, region, country code: France (F), Lebanon (L), Spain (S), and Germany (G).

${ }^{y}$ Climate code: Atlantic (A), continental (C), and Mediterranean (M).

${ }^{\mathrm{z}}$ Vines either asymptomatic or showing Black Dead Arm-like or esca-like foliar symptoms during the growing season. Numbers in bold italics indicate number of asymptomatic vines examined as controls. 
season. Their appearance was first associated with a severe form of BDA-like symptoms with either numerous wilted leaves or large interveinal wilting zones (gray to pale green). After several weeks, canes generally became completely dry, with brittle and palebrown necrosis, or they severely declined (Fig. 3J). After some days or weeks, such vines were also indistinguishable from the typical apoplectic form classically ascribed to esca. Depending on the vineyard-year interaction, the rate of development from BDAlike symptoms toward typical esca symptoms, with either red bright or yellow colors, differed in speed. For example, in 2006, symptom progression was rather slow in Cénac and Latresne, where most vines still showed BDA-like symptoms at the end of June. However, in 2005, symptom evolution was more rapid in June, showing a predominance of mixed or esca symptoms in Ludon-Médoc and Latresne in less than 3 weeks.

Occurrence of xylem stripes in European and Lebanese vineyards. As previously described by Larignon et al. (22), in all cases, longitudinal discolored stripes were located superficially in the outer xylem of the trunk and arms (Fig. 4). The stripes appeared concomitantly with foliar symptoms and in trunk xylem areas leading to canes bearing symptomatic leaves (Fig. 4A, B, and J). At an early development stage ( 1 to 3 days old), the altered wood appeared as a yellowish-orange stripe, then orange-brown, similar to the color of oxidized tissues (Fig. 3D, E, and H). In some cases, recent stripes appeared discontinuously and often extended along the trunk (Fig. 3E-G, J, and K) but not always beyond the graft union. No precise initial points of developing necrosis could be identified in order to explain the origin of these stripes; neither a precise wound nor an altered zone that could possibly obstruct the vessels. In the most severe cases-namely, apoplectic formsseveral stripes (often two to three) were observed which were often wide ( 2 to $5 \mathrm{~cm}$ ) and deep ( 1 to $2 \mathrm{~mm}$ ). It was generally observed that the number or the extent of lesions (depth, length, or width) was associated with an increased severity of the foliar symptoms. Later in the season, several weeks after the vines had expressed foliar symptoms, the longitudinal stripes generally turned brown (Fig. 3F and $\mathrm{K}$ ), indicating the beginning of a perennial wood lesion.

The occurrence of a xylem discoloration under the bark from 2004 to 2007 was studied using 688 vines comprising 581 (84.5\%) leaf-symptomatic vines and $107(15.5 \%)$ asymptomatic ones (control). Most of the asymptomatic vines (98.1\%) showed no longitudinal stripes. Among the symptomatic vines, only $4.3 \%$ lacked the stripe, showing a strong correlation between foliar symptom occurrence and the stripe (Fisher exact test, two-tailed, $P<0.0001$; $\left.\chi^{2}=519.1 ; \mathrm{df}=1 ; P<0.001\right)$. Symptomatic vines were used to test the hypothesis that the presence of the stripe was independent of the kind of foliar symptoms (B and BE versus E), including 104 vines assessed with BDA-like symptoms. Of these 104 vines, $97.1 \%$ exhibited at least one xylem stripe in the wood, confirming that these lesions are frequently related to this kind of foliar symptoms, as previously reported (21). The vines in which no stripe was seen $(2.9 \%)$ showed rather mild BDA-like or esca foliar symptoms associated with necrosis already existing in the wood; in particular, fresh necrosis extending from pruning wounds. Similarly, among the other 477 vines that showed esca-like symptoms, $95.4 \%$ also exhibited at least one longitudinal stripe. The proportions of symptomatic vines showing at least one stripe were not significantly different between vines showing either BDA-like or esca symptoms (Fisher's exact test, two-tailed, $P=0.60 ; \chi^{2}=0.62, \mathrm{df}=1 ; P$ $=0.43$ ).

Three types of relationship between stripe location and vine architecture were identified in 452 vines. First, $47 \%$ of the vines exhibited at least one stripe which had formed in a sap route close to a large externally visible canker lesion zone (Fig. $3 \mathrm{H}$ ), similar to that described by Branas (5). Second, $31 \%$ of the vines showed a stripe on a line from either side of pruning wounds (Fig. 3G). Third, $22 \%$ of the vines showed a stripe which was associated with both locations. Overall, $69 \%$ of the stripes were located close to a previous necrosis. One year after the first examination in 2007, 29 of the 34 vines examined in 2008 in the Latresne vineyard showed longitudinal necrotic lesions in the wood that corresponded exactly to the stripes labeled initially. As described in other studies $(5,17)$, 18 stripes were found to develop into longitudinal canker lesions 1 year later (Fig. 3C and K). The others (11) were found to have merged with previously existing longitudinal canker lesions and were covered over by newly generated wood tissues.

\section{Discussion}

The diagnosis of esca sensu lato in grapevine during summer is complicated by the fact that symptom expression varies between black and white cultivars and with the location, and also because of many reports with different descriptions. Previous studies $(13,23,27,30,42,43)$ suggested that BDA foliar summer symptoms could be related to those of esca. Here, we had originally advanced the hypothesis that the early symptoms of drying zones and early reddening (black cultivar) or yellowing (white cultivar) previously attributed to BDA constitute a transient phase in symptom development within the esca syndrome. This notion was supported by the fact that foliar symptoms were seen to develop during the course of the season and could be associated with wood stripes, a typical esca symptom $(1,8,14)$.

Regarding the leaves, our regular observations showed that those on esca-diseased grapevines may host highly variable symptoms depending on their severity and age, as largely suggested by literature. In contrast to most previous descriptions, esca symptoms were not separated into mild or apoplectic forms but according to a classification based on a gradual scale of severity, starting from some leaves showing only discolorations up to a complete vine wilting. At the early stage, in all sites, mild symptoms frequently corresponded to either a wine-red discoloration on black-berried cultivars or a yellowish discoloration on white-berried ones. More severe symptoms were generally characterized by the occurrence of interveinal drying zones (symptoms previously attributed to BDA). In most severe cases, symptomatic leaves fell or dry rapidly, corresponding to an acute form. The first appearance of pale green-

Table 5. Disease incidence in the five vineyards surveyed in Aquitaine region: percentage of vines with trunk symptoms and number and percentage of vines showing leaf damage, with either Black Dead Arm-like or esca-like foliar symptoms, during the growing season ${ }^{y}$

\begin{tabular}{lccc}
\hline Municipality & Years of observation & Trunk-affected vines (\%) & Number of vines showing leaf damage (\%) \\
\hline Ludon-Médoc & 2004 & $45.2 \mathrm{~b}$ & $223(22.3) \mathrm{e}$ \\
& 2005 & $49.8 \mathrm{a}$ & $72(7.2) \mathrm{g}$ \\
Cénac & 2004 & $31.4 \mathrm{~d}$ & $93(18.6) \mathrm{ef}$ \\
& 2005 & $38.8 \mathrm{c}$ & $84(16.8) \mathrm{f}$ \\
Latresne & 2006 & $48.2 \mathrm{ab}$ & $141(25.6) \mathrm{de}$ \\
& 2004 & Not recorded & $487(45.4) \mathrm{b}$ \\
Ramouzens & 2005 & $9.4 \mathrm{e}$ & $175(35) \mathrm{cd}$ \\
Labarrère & 2006 & $9.6 \mathrm{e}$ & $278(55.6) \mathrm{a}$ \\
\hline
\end{tabular}

${ }^{y}$ Means followed by the same letter are not significantly different.

${ }^{\mathrm{z}}$ In Ramouzens, the percent affected vines was biased because only the dead vines were recorded. 

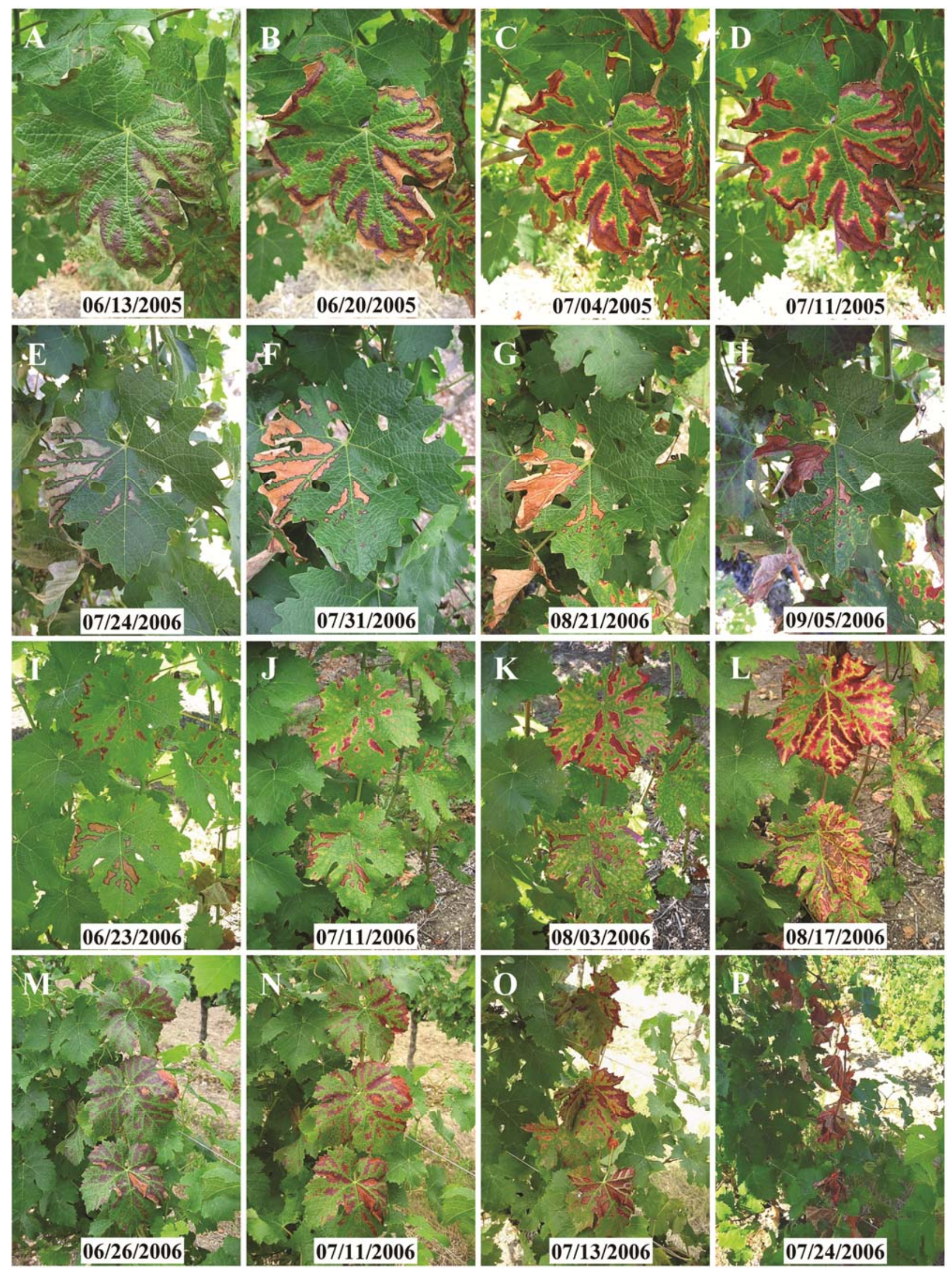

Fig. 2. Four examples of the evolution of mild symptoms on leaves affected by esca on a black cultivar, 'Cabernet sauvignon', recorded in summer 2005 and 2006 in the Aquitaine Region. On the left, $\mathbf{A}$ and $\mathbf{B}$, recent gray dry zones or I and $\mathbf{M}$, older brown dried zones surrounded by red-wine coloration; in the middle, $\mathbf{B}$ and $\mathbf{F}$, the gray zones became completely dry and orange-brown; on the right, $\mathbf{C}, \mathbf{D}$, and $\mathbf{H}$, appearance of bright red or yellow coloration, often instead of the red wine pigmentation (C and $\mathrm{D}$ compared with A and B, J compared with I, N compared with $M$ ), leading to $D, L$, and $\mathbf{O}$, a typical tiger striped pattern of esca. In two cases (I-L and M-P), the severity of symptoms significantly increased as leaves aged. 
to-gray wilting zones before drying $(42,47)$ was a frequent and original observation in our surveys. This observation is not in complete agreement with some initial descriptions of esca $(7,11)$, in which symptoms were described as starting from discolorations, with the possible development of necrotic zones in their center. Such a sequence of symptoms, starting from a discoloration and developing in a drying zone, was also observed in our survey and corresponded to mild symptoms. However, such an evolution from discolorations to drying was much less frequent than the early symptoms described above. Following the appearance of the first symptoms, temporal changes in symptomatology on the leaves that did not fall included an increase in severity, with the extension of drying zones or discolored areas as previously reported $(8,11,47)$. When there was no increase in severity, there was generally a change in color only: in black-berried cultivars, for example, a light red coloration often followed the initial wine-red coloration. During the course of the summer, further discoloration spots, corresponding to mild secondary symptoms, sometimes appeared on other leaves or on those previously altered. All these types of symptom development contributed to providing the typical esca symptoms (i.e., a tiger-stripe pattern; 11,32,42).

At the plot scale, the results for the foliar symptoms revealed a major progressive pattern in all the vineyards surveyed in Aquitaine: the symptoms increased up to a maximum more or less regularly in late July or early August. After this peak, new symptomatic vines continued to appear up to September, although much less frequently. All symptomatic vines showed the development of BDA-like symptoms to esca-like symptoms during the summer, confirming the results obtained for the leaves examined individually. The very high frequency of vines showing such a progressive development clearly favors a single syndrome, rather than two different and successive diseases always occurring in the same sequence. In contrast to conclusions drawn from previous data $(1,11,42)$, disease development within the season clearly corresponded to a more or less regular process. This pattern was observed regardless of the site and the year, although 2005 was a dry year and the others more humid. This tends to indicate that the development of the disease may be dependent upon a progressive phenomenon which would lead to this intensification of symptoms.

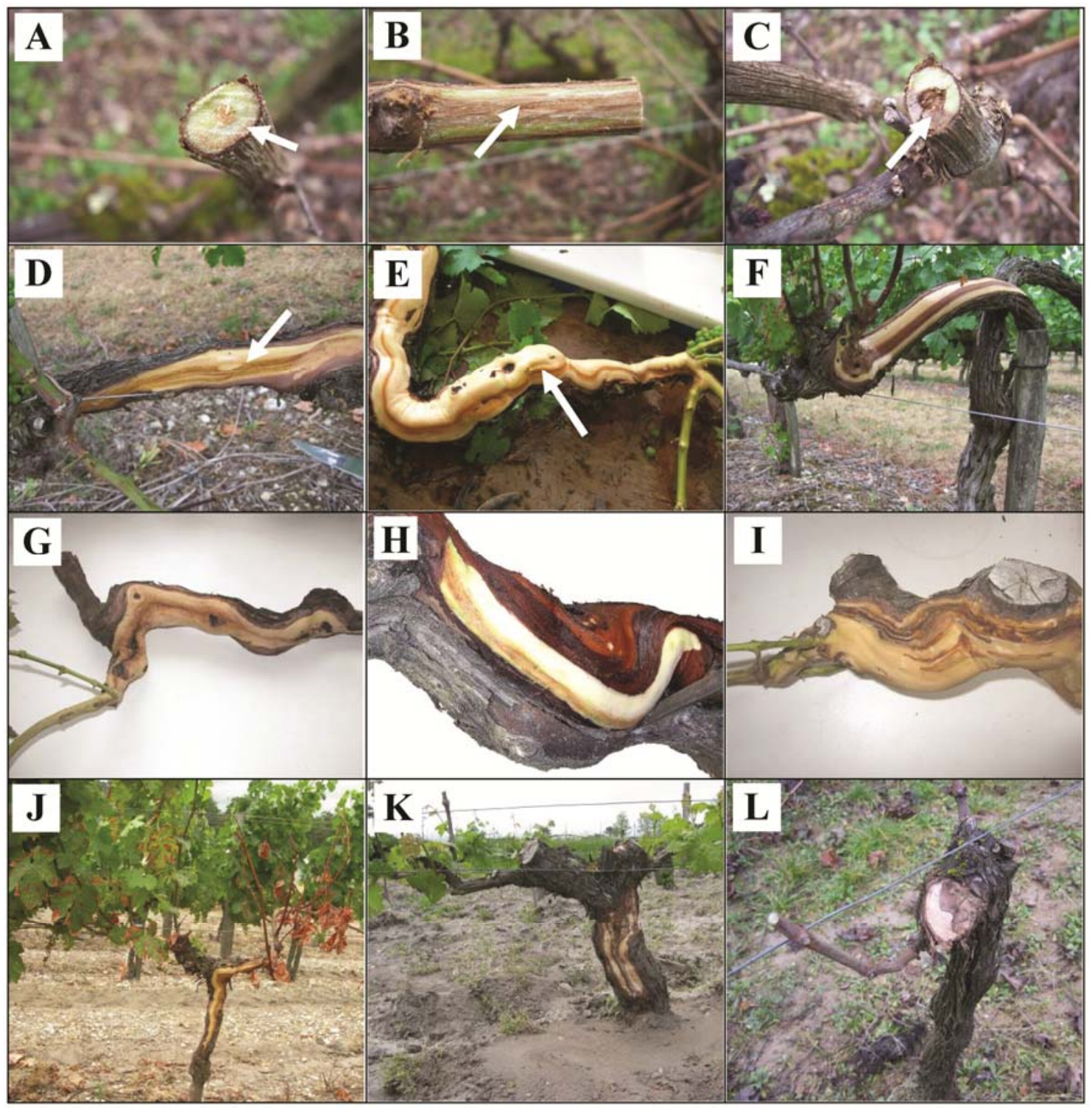

Fig. 3. Examples of wood symptoms associated with esca on either canes or trunks. A, Fresh orangey stripe lesion (white arrow) in the outer xylem under the bark of a transversally cut-cane; $\mathbf{B}$, similar lesion observed after the removal of the bark; C, evolution after some months of a longitudinal lesion in a wedge-shaped canker; D, superficial and discontinuous lesion recently formed; $\mathbf{E}$, similar lesion that appeared along a cane down to the bottom of a trunk; $\mathbf{F}$, other lesion that became more brown some weeks after the foliar symptom appearance; $\mathbf{G}$, longitudinal stripe that was seen in places under the bark, resulting from pruning wounds; $\mathbf{H}$ and $\mathbf{I}$, longitudinal stripes that occurred along dead wood zones; J, longitudinal stripe in relationship to leaf wilting and a severe form on one arm; $\mathbf{K}$, old longitudinal stripe that formed a canker lesion; L, V-shaped canker that may often originate from a longitudinal lesion. 
Such a general pattern has already been described by Marchi et al. in 2006 (32). It should be highlighted that the first signs of esca expression on a leaf appeared at the end of spring, when mean temperatures progressively increased and water availability decreased. Therefore, further studies are needed in order to better understand the links between environmental conditions (temperature, rain, and water availability within the plant) and disease expression during the season, as well as the microbial activity in the grapevine wood.

In Aquitaine, significant differences in disease incidence between sites were noticeable. All monitored vineyards in the Bordeaux area exhibited a high percentage of leaf-symptomatic vines ( $>15 \%$ in eight of nine cases; Table 5), which was much higher than the mean incidence (less than 5\%) reported in France (19). In this study, the percentage of trunk-affected vines was based, mostly, on visual observations of dead or missing vines and dead or missing arms. This trunk-affected scale was indicative and relevant because all the Aquitaine vineyards surveyed were selected beforehand with a high incidence of esca and low mortality due to other causes (Eutypa dieback, Armillaria root rot, soil effect, and so on). Moreover, a positive and significant correlation has been demonstrated between the incidence of dead vines (percent) and the mean necrotic area (percent) in the wood due to inner lesions typical of esca (29). Thus, both variables (percentage of vines showing typical foliar symptoms and percentage of trunk-affected vines) are inseparable and perfectly illustrate the incidence of the disease. Leaf symptoms are generally the first signs of the decline. Trunk symptoms (externally visible) constitute the ultimate consequence of the esca disease. Incidentally, the only Lyra-trained vineyard (Latresne) showed the highest percentage of vines expressing foliar symptoms $(55.6 \%)$ but one of the lowest incidences of trunkaffected vines. From this particular site, it can be hypothesized that there is an influence of the training system and the associated pruning practice on esca incidence. Lyra-training system is based on the formation of two long arms (approximately $80 \mathrm{~cm}$ in length) bearing spurs distributed every 20 to $30 \mathrm{~cm}$. Arms of cordons that form with very short arms, such as Guyot forms, where an increased concentration of necrosis is present in a limited wood zone (2426), often die more slowly. Thus, cordons can express trunk diseases foliar symptoms more often and longer. Such an effect of a pruning method has been also reported in rootstock mother grapevines (29). Therefore, we would recommend that the relationship between the training system and foliar expression of esca be further studied in order to identify and encourage the use of lessconducive training systems $(11,16,24-26,38)$. We also recommend the use of the symptom scale developed in this study, allowing observers to assess completely and precisely the incidence of esca syndrome. A two-date survey, at veraison and before harvest, would be sufficient to look for the evolution of foliar symptoms, including the transitory phase. The scale can be particularly useful for the selection of tolerant cultivars or determining the role of cultural factors.

In this study, we focused on an often neglected essential vine wood symptom, the occurrence of longitudinal xylem stripes just under the bark that mostly develop into perennial wood lesions, as already suggested (21). In the west-palearctic regions where our study was conducted, our results confirm that this wood alteration is a frequent and typical symptom of esca decline, as reported previously $(1,8,14,23,27)$. The percentage of leaf-symptomatic vines exhibiting such a stripe was very high $(95 \%)$, regardless of whether the leaf disorder was identified as BDA-like or esca-like. All of our observations in various vineyards in France and abroad, including some additional cases in Morocco and Italy (data not shown), showed at least one wood stripe on the same sap route as those of the cane bearing foliar symptoms. Our understanding in favor of a unique syndrome rather than two different diseases is substantiated by the fact that these stripes have been reported as a common symptom in both esca and BDA. This view is also strongly supported by the fact that, during the survey, no difference was observed between the severe form of BDA (22) and the apoplectic form of esca. Although there was no precise count, the number of stripes per vine and their size appeared visually to be

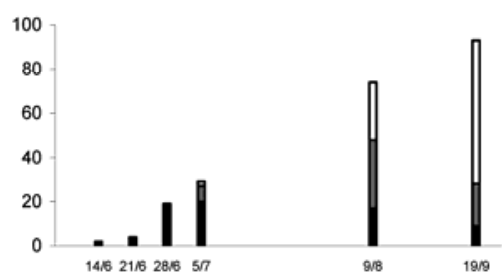

Cénac - 2004

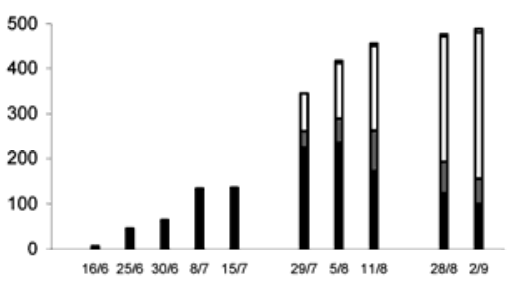

Latresne - 2004

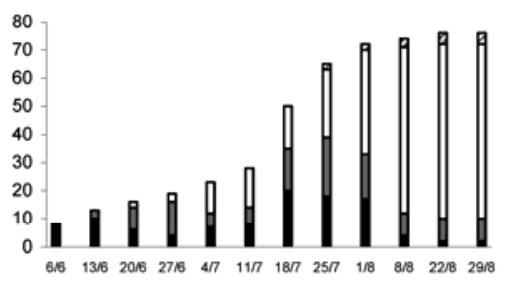

Ludon Médoc - 2005

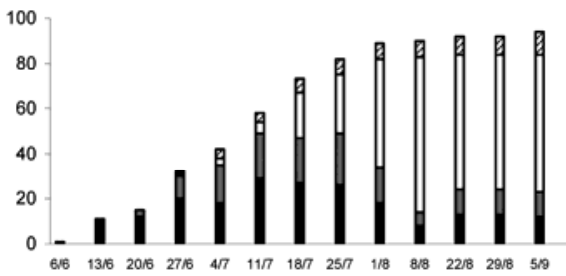

Cénac - 2005

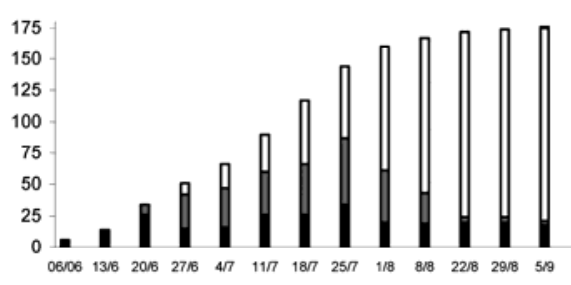

Latresne - 2005

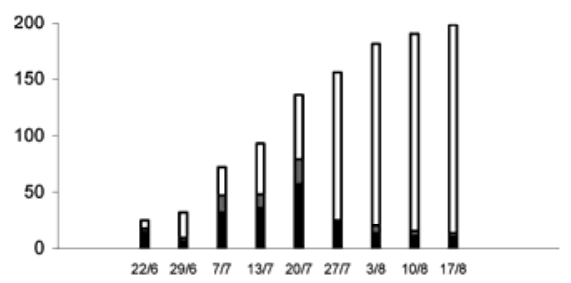

Ramouzens - 2006

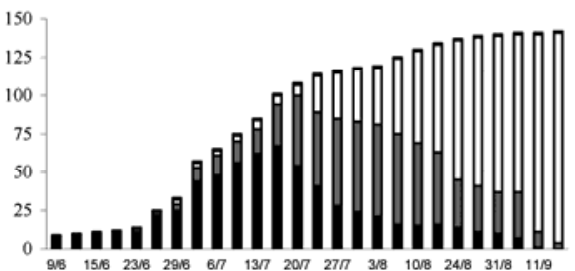

Cénac - 2006

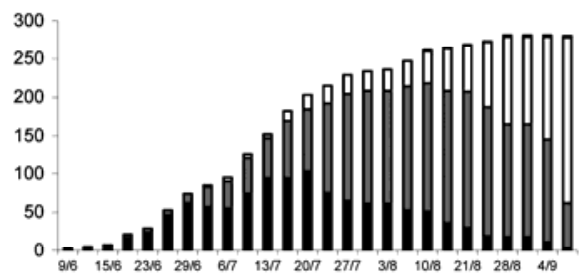

Latresne - 2006

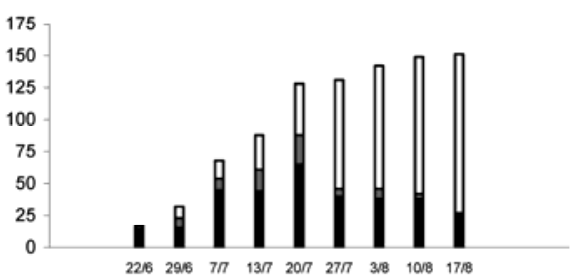

Labarrère - 2006

Fig. 4. Evolution of foliar symptom observed in five vineyards in summer in the Aquitaine region (southwest of France). Each date represents the incidence of vines showing either (i) Black Dead Arm-like symptoms (dark), (ii) esca-like symptoms (white), (iii) simultaneous symptoms corresponding to both symptomologies (gray), or (iv) apoplectic form (hatched area). 
connected with foliar symptom severity, such as wilting and drying zones on leaves. This was further substantiated by the fact that the few vines we examined not showing any stripes $(4.3 \%)$ showed mild foliar symptoms only (mostly discolorations restricted to some leaves). Interestingly, this particular wood symptom has, thus far, not been reported in the areas where apoplectic or severe forms of esca are not seen, for example in Chile (J. Auger, personal communication). Therefore, further studies should be carried out in other geographical locations (namely, in climatic zones apparently less conducive to acute forms of esca) to learn more about the presence of wood symptoms. Our observations of fresh stripes showed that the altered wood is sometimes discontinuous, with a yellowish-orange discoloration that is similar to oxidized tissue. The stripes were seen close to but not strictly connected to necrotic zones. Moreover, the origin of these longitudinal alterations could not be visually connected to a precise initial point of visible necrosis, neither a precise wound nor an altered zone that could possibly have occluded the vessels. Thus, the exact origin of the stripes remains unclear and two main hypotheses, not mutually exclusive, may be put forward. The stripes may arise from (i) a fungal invasion, either from the outer bark or close to the inner necrosis, leading to vessel occlusions or to toxin diffusion, or (ii) a sudden sap disruption, which is followed by foliar symptoms, as already suggested $(23,27)$. An interesting point of etiology in the esca syndrome is that there are nonrevertible wood degradations (stripes or necrosis) associated with a revertible process of foliar symptoms (symptom appearance varies from year to year). It may be hypothesized that, each season, the newly formed vessels, redefining the vascular system of the plant, may affect the foliar symptoms' appearance (26). Other factors such as plant defense efficiency or the pruning type, that may interfere with the vascular system, may also be of importance in foliar symptom development $(16,26)$.

Finally, from these two surveys, one in Aquitaine and another in European and Lebanese regions, we conclude that the esca syndrome encompasses a large diversity of foliar symptoms, due to severity or variations between red and white cultivars and a significant evolution during the course of the season. Furthermore, this syndrome is characterized by an original wood symptom, the xylem discolored stripe, appearing simultaneously with foliar symptoms and which could be responsible for their development. A better understanding of the origin of these stripes may be a key element for explaining the development of foliar symptoms and for making progress in the etiology of this complex syndrome.

\section{Acknowledgments}

This research was conducted with the specific financial support of FranceAgrimer, Egide (France-Lebanon), Aquitaine, and Basque Country regions (Euskadi project). We thank farmers, observers, and colleagues for their kind reception and for providing disease data: T. Lusseau (INRA, Bordeaux, France), N. David and C. Vidal (Chambre d'Agriculture, Gers, France), M. Boulay (LVMH-Epernay-France), P. Kuntzmann (IFVV-Alsace, France), H. Kassemeyer and M. Fisher (Weinbauinstitut, Freiburg im Breisgau, Germany), and C. Magnien (DGAL-Burgundy, France); M. Leyo, A. Defives, I. Aleksandrova, and F. Boiffard for their active technical contribution; and L. Mugnai, S. Ahmed, and S. Hayes for their helpful revision of the manuscript.

\section{Literature Cited}

1. Arnaud, G., and Arnaud, M. 1931. Esca, Polypores et Maladies fongiques diverses du tronc. Pages 428-444 in: Traité de Pathologie Végétale-Encyclopédie Mycologique III. Lechevalier et Fils, ed., Paris.

2. Auger, J., Esterio, M., Ricke, G., and Pérez, I. 2004. Black dead arm and basal canker of Vitis vinifera cv. Red Globe caused by Botryosphaeria obtusa in Chile. Plant Dis. 88:1286.

3. Berraf, A., and Péros, J. P. 2005. Importance of Eutypa dieback and esca in Algeria and structure of the associated fungal community. J Int. Sci. Vigne Vin 39:121-128.

4. Bonfiglioli, R., and McGregor, S. 2006. The Botryosphaeria conundrum-a New Zealand perspective. Aust. N. Z. Grapeg. Winem. 512:49-53.

5. Branas, J. 1974. Apoplexie. Pages 796-802 in: Viticulture, Montpellier.

6. Burruano, S., Mondello, V., Conigliaro, G., Alfonzo, A., Spagnolo, A., and Mugnai, L. 2008. Grapevine decline in Italy caused by Lasiodiplodia theobromae. Phytopathol. Mediterr. 47:132-136.

7. Chiarappa, L. 1959. Wood decay of the grapevine and its relationship with black measles disease. Phytopathology 49:510-519.

8. Ciferri, R. 1955. Il mal dell'esca e l'apoplessia della vite. Pages 982-988 in:
Manuale di Patologia Vegetale. Societa Editrice Dante Alighieri, ed., Roma.

9. Cristinzio, G. 1978. Gravi attachi di Botryosphaeria obtusa su vite in provincia di Isernia. Inf. Fitopatol. 28:21-23.

10. Darrieutort, G., and Lecomte, P. 2007. Evaluation of a trunk injection technique to control grapevine wood diseases. Phytopathol. Mediterr. 46:50-57.

11. Dubos, B. 2002. Le syndrome de l'esca. Pages 127-142 in: Maladies Cryptogamiques de la Vigne, 2nd ed. Féret, Bordeaux, France.

12. Fischer, M. 2002. A new wood-decaying basidiomycete species associated with esca of grapevine: Fomitiporia mediterranea (Hymenochaetales). Mycol. Prog. 1:315-324.

13. Fussler, L., Kobes, N., Maumy, M., Bertrand, F., Grosman, J., and Savary, S. 2008. A characterization of grapevine trunk diseases in France from data generated by the National Grapevine Wood Disease Survey. Phytopathology 98:571-579.

14. Galet. 1995. Apoplexie. Pages 80-85 in: Précis de Pathologie Viticole. JF Impression, St. Jean de Védas, France.

15. Geoffrion, R. 1971. L'esca de la vigne dans les vignobles de l'ouest. Phytoma 23:21-31.

16. Geoffrion, R., and Renaudin, I. 2002. Tailler contre l'esca de la vigne. Phytoma 554:23-27.

17. Gubler, W. D., Rolshausen, P. E., Trouillas, F. P., Úrbez-Torres, J. R Voegel, T. M., Leavitt, G. M., and Weber, E. A. 2005. Grapevine trunk diseases in California. Pract. Winery Vineyard (Jan/Feb):1-9.

18. Kasimatis, A. N. 1975. Abstracts and reviews. Am. J. Enol. Vitic. 26:172 173.

19. Kobès, N., Grosman, J., and Pleynet, M. 2006. L'observatoire des maladies du bois de la vigne-Bilan de 3 années d'observations. Pages 15-23 in: AFPP-8ème Conférence Internationale sur les Maladies des Plantes. Tours, France.

20. Larignon, P. 2004. Réflexions sur l'esca. Phytoma 576:28-31.

21. Larignon, P., and Dubos, B. 2001. Le Black Dead Arm-maladie nouvelle à ne pas confondre avec l'esca. Phytoma 538:26-29.

22. Larignon, P., Fulchic, R., Ceré, L., and Dubos, B. 2001. Observation on black dead arm in French vineyards. Phytopathol. Mediterr. 40:336-342.

23. Lecomte, P., Darrieutort, G., Defives, A., Louvet, G., Liminana, J.-M., and Blancard, D. 2006. Observations of Black Dead Arm symptoms in Bordeaux vineyards: evolution of foliar symptoms, localisation of longitudinal necroses, questions, hypotheses. "Integrated Protection in Viticulture" IOBC/wprs Bull. 29:93-94.

24. Lecomte, P., Darrieutort, G., Laveau, C., Blancard, D., Louvet, G. Goutouly, J.-P., Rey, P., and Guérin-Dubrana, L. 2011. Impact of biotic and abiotic factors on the development of esca decline disease. "Integrated Protection and Production in Viticulture" IOBC/wprs Bull. 67:171-180.

25. Lecomte, P., Darrieutort, G., Liminana, J. M., Louvet, G., Tandonnet, J.-P., Guerin-Dubrana, L., Goutouly, J.-P., Gaudillère, J.-P., and Blancard, D. 2008. Eutypiose et esca. I. Eléments de réflexion pour mieux appréhender ces phénomènes de dépérissement. Phytoma 615:42-48.

26. Lecomte, P., Darrieutort, G., Liminana, J. M., Louvet, G., Tandonnet, J.-P., Guerin-Dubrana, L., Goutouly, J.-P., Gaudillère, J.-P., and Blancard, D. 2008. Eutypiose et esca II. Vers une gestion raisonnée des maladies de dépérissement. Phytoma 616:37-41.

27. Lecomte, P., Leyo, M., Louvet, G., Corio-Costet, M. F., Gaudillère, J.-P., and Blancard, D. 2005. Le Black dead arm, genèse des symptômes-Observations au vignoble en Bordelais et réflexions en lien avec l'esca. Phytoma 587:29-37.

28. Lehoczky, J. 1974. Black dead-arm disease of grapevine caused by Botryosphaeria stevensii infection. Acta Phytopathol. Acad. Sci. Hung. 9:319327.

29. Liminana, J. M., Pacreau, G., Boureau, F., Menard, E., David, S., Himonnet, C., Fermaud, M., Goutouly, J.-P., Lecomte, P., and Dumot, V. 2009. Inner necrosis in grapevine rootstock mother plants in the Cognac area (Charentes, France). Phytopathol. Mediterr. 48:92-100.

30. Luque, J., Martos, S., Aroca, A., Raposo, R., and Garcia-Figueres, F. 2009. Symptoms and fungi associated with declining mature grapevine plants in northeast Spain. J. Plant Pathol. 91:381-390.

31. Luque, J., Martos, S., and Philipps, A. J. L. 2005. Botryosphaeria viticola sp. nov. on grapevines: a new species with a Dothiorella anamorph. Mycologia 97:1111-1121.

32. Marchi, G., Peduto, F., Mugnai, L., Di Marco, S., Calzarano, F., and Surico, G. 2006. Some observations on the relationship on manifest and hidden esca to rainfall. Phytopathol. Mediterr. 45:S117-S126.

33. Mugnai, L., Graniti, A., and Surico, G. 1999. Esca (Black Measles) and brown wood-streaking: two old and elusive diseases of grapevines. Plant Dis. 83:404-418.

34. Muruamendiaraz, A., and Legorburu, F. J. 2009. Suitability of an increment borer as a sampling device for grapevine trunk disease. Phytopathol. Mediterr. 48:145-149.

35. Péros, J.-P., Berger, G., and Jamaux-Despréaux, I. 2008. Symptoms, wood lesions and fungi associated with esca in organic vineyards in LanguedocRoussillon (France). J. Phytopathol. 156:297-303.

36. Phillipps, A. J. L. 2002. Botryosphaeria species associated with diseases of grapevines in Portugal. Phytopathol. Mediterr. 41:3-18.

37. Ravaz, L. 1909. Sur l'Apoplexie de la Vigne. Prog. Agric. Vitic. 52:574 579. 
38. Reynier, A. 2003. Maladies du bois dues à des champignons. Pages 436-452 in: Manuel de Viticulture, Tec et Doc. Lavoisier ed., Paris.

39. Rovesti, L., and Montermini, A. 1987. Un deperimento della vite causato da Sphaeropsis malorum diffuso in provincia di Reggio Emilia. Inf. Fitopatol. 37:59-61.

40. Savocchia, S., Steel, C. C., Stodart, B. J., and Somers, A. 2007. Pathogenicity of Botryosphaeria species isolated from declining grapevines in sub tropical regions of Eastern Australia. Vitis 46:27-32.

41. Sergeeva, V. 2004. Multiple incidences of Botryosphaeria, Pestalotiopsis and Greenaria on dormant wood of grapevines in Australia. Aust. N. Z. Grapeg. Winem. 485:54-55.

42. Surico, G., Mugnai, L., and Marchi, G. 2006. Older and more recent observations on esca: a critical overview. Phytopathol. Mediterr. 45:68-86.
43. Úrbez-Torres, J. R. 2011. The status of Botryosphaeriaceae species infecting grapevines. Phytopathol. Mediterr. 50:S5-S45.

44. Úrbez-Torres, J. R., Leavitt, G. M., Voegel, T. M., and Gubler, W. D. 2006 Identification and distribution of Botryosphaeria spp. associated with grapevine cankers in California. Plant Dis. 90:1490-1503.

45. van Niekerk, J. M., Crous, P. W., Fourie, P. H., and Halleen, F. 2004. DNA phylogeny, morphology and pathogenicity of Botryosphaeria species on grapevines. Mycologia 96:781-798.

46. van Niekerk, J. M., Fourie, P. H., Halleen, F., and Crous, P. W. 2006. Botryosphaeria spp. as grapevine trunk disease pathogens. Phytopathol. Mediterr. 45:S43-S54.

47. Viala, P. 1926. Recherches sur les maladies de la vigne: esca. Ann. Epiphyties 12:1-108. 